6. Лавриненко В.Н. Психология и этика делового общения - Изд. ЮнитиДана 2012 г.

7. Мерлин В.С. Психология индивидуальности - Изд. Модэк 2009 г.

8. Носкова О.Г. «Психология труда». МИц «Академия» 2006 г.

\title{
ОСОБЕННОСТИ РАЗВИТИЯ И СТАНОВЛЕНИЯ ЛИЧНОСТИ В УСЛОВИЯХ УСИЛИВАЮЩЕГОСЯ ВОЗДЕЙСТВИЯ КОМПЬЮТЕРНЫХ ФОРМ ВЗАИМОДЕЙСТВИЯ В СТРУКТУРЕ МЕЖЛИЧНОСТНЫХ ОТНОШЕНИЙ ЮНОШЕЙ И ДЕВУШЕК
}

Кузьмина К.Е.

Компьютерное общение стало неотъемлемой частью жизни современного человека. Социальные сети дают неограниченные возможности для общения, даже если люди находятся на большом расстоянии друг от друга или заняты другими делами и не могут провести время вместе.

Можно констатировать, что современные юноши и девушки больше общаются с помощью социальных сетей, чем в реальности. Это обусловлено, по крайней мере, двумя причинами. Во-первых, они с интересом и огромным удовольствием погружаются в мир информации и используют современные достижения техники. Более того компьютеризация и информатизация всех сфер жизнедеятельности человека, в том числе и его личных отношений является закономерным процессом развития современной цивилизации, что в свою очередь требует психологического осмысления трансформаций в таких условиях самого человека и его личности.

Во-вторых, современные юноши и девушки часто не имеют возможности общаться «в живую». Это связано и с отсутствием времени (большие нагрузки в школе, многие взрослеющие люди получают дополнительное образование, посещают кружки, секции и т.п.), и с банальным отсутствием пространства, места, где они могли бы совместно провести время. Пребывание юноши (девушки) в школе и центрах дополнительного образования ограничено учебным процессом: как только заканчиваются занятия, они обязаны покинуть учебное заведение. Проведение детских дискотек, вечеров встреч и т.П. очень сильно ограничено требованиями безопасности. Все развлекательные и культурно-досуговые центры являются платными.

Общение в социальных сетях становится самым доступным способом общения со сверстниками для современного взрослеющего человека. Вызывает опасения большая вероятность того, что это общение в силу изложенных выше причин оказывается единственным возможным.

Таким образом, в системе деятельностей современного юноши и девушки, в которой разворачивается взросление личности (Л.С. Выготский, В.В. Давыдов, Д.И. Фельдштейн, Д.Б. Эльконин), огромное значение приобретают компьютеризированная деятельность и компьютеризированное общение, все более активно «вовлекая» личность в процессы алгоритмизации и структурирования опыта, изменяя прежние способы осмысления, понимания, определения объективного мира, оказывают особое (и неоднозначное) влияние 
на систему взаимоотношений индивида с социумом. Отсюда позитивна актуальность объективного изучения и выявления психологических особенностей личности, для которой компьютеризированная деятельность и общение выступают одним из средств познания субъективной ценности другого человека и одновременно способом индивидуального определения субъектных принципов взаимодействия с ним.

В данной статье мы попытались сформулировать проблему особенностей и механизмов становления личности юноши (девушки) в условиях усиливающегося воздействия на неё общения в социальных сетях, замены реального общения различными формами опосредованного компьютерными технологиями общения со сверстниками, а также взаимодействия с виртуальными субъектами.

Как известно межличностные отношения являются основной средой формирования психических новообразований в юношеском возрасте (И.С. Кон, А.В. Петровский, Д.И. Фельдштейн). Соответственно существенное изменение этой среды, а именно опосредование отношений компьютеризированными способами взаимодействия, включение в эти отношения с помощью социальных сетей малознакомых или даже незнакомых личностей, возможность мистификации в виртуальном мире и т.д., оказывает влияние и на развитие личности в этом возрасте.

В период ранней юности (от 14-15 до 18 лет соответственно возрастной периодизации И.С. Кона) потребность в общении максимально обострена и достигает своего наивысшего уровня развития. Общение играет огромную роль в жизни юноши, пронизывая все сферы его жизнедеятельности.

Особенностью межличностного общения в период юности является «переориентация» общения с родителями, учителями и вообще старшими на ровесников. Общение со сверстниками дает возможность юноше (девушке) удовлетворить свою жизненно важную потребность в социальном самоутверждении и эмоциональном контакте. Умение заслужить любовь и уважение равных товарищей, имеет для их самоуважения решающее значение (Н.П. Аникеева, .С. Кон, А.В. Мудрик, Д.И. Фельдштейн). Интимноличностное, доверительное общение в юношеском возрасте (В.Э. Пахальян, Т.П. Скрипкина и др.) обнаруживает потребность личности в понимании, сочувствии, самораскрытии. (Н.П. Аникеева, И.М. Захарова, Я.Л. Коломинский, А.В. Мудрик, И.С. Полонский). Ученые выделяют следующие особенности общения в юности: максимально обостряется потребность в общении; наблюдается расширение общения за счет увеличения числа групп, в которые входит взрослеющий человек; возрастает интенсивность общения; предметом общения становится сам юноша (девушка) как субъект отношений; особое значение приобретает общение со сверстниками, в частности, дружеское общение; ярко выражено стремление к пониманию и сочувствию; происходит снижение контакта со взрослыми, снижается уровень доверительности в общении с ними; возникает потребность в уединении для «погружения в себя».

В условиях компьютеризации начинается активный поиск и установление новых контактов в социальных сетях. У современного юноши и девушки 
появляются неограниченные возможности устанавливать и развивать контакты не только с ближайшим окружением, но и с совершенно незнакомыми личностями, имеющими возможно совершенно иной культурный опыт, иные ценности и иные представления о жизни. Возрастание же роли межличностного общения в жизни юноши (девушки) ученые (Н.П. Аникеева, И.С. Кон, А.В. Мудрик, Д.И. Фельдштейн) связывают с потребностью в личностном самоопределении, с появлением необходимости, с одной стороны, в новом опыте, с другой - в признании, защищенности, доверии. Это означает, что взаимодействие посредством социальных сетей с представителями иных культур (как разных этносов, так и разных социальных слоев) казалось бы расширяет опыт юноши, обеспечивая ему выбор собственной модели поведения, собственных ценностей. На практике же оказывается, что такая вариативность жизненных моделей, с которой сталкивается современный юноша (девушка) посредством сети Интернет и СМИ не только не обеспечивает личностное самоопределение, но и приводит к дезориентации современной молодежи. Это проявляется в чувстве незащищенности и одиночества. Признание и доверие, которые так важны для благополучного развития личности, современный юноша (девушка) может находить в социальных сетях и быть непризнанным в реальном мире. Вряд ли такое положение дел можно рассматривать как благоприятное для личности.

В исследованиях отечественных психологов (Н.П. Аникеева, И.М. Захарова, Ю.П. Канищев, Я.Л. Коломинский, Г. Крайг, И.Ю. Кулагина, А.В. Мудрик, И.С. Полонский, Т.П. Скрипкина, Д.И. Фельдштейн, Л.М. Фридман и др.) было показано, что предметом юношеского типа общения является сам юноша (девушка) как субъект отношений. Содержанием общения для него является познание своего «Я», определение своей позиции в реальной жизни и системах отношений, определение своего будущего, профессиональное самоопределение, реализация себя в актуальной деятельности и поиске адекватных способов социального самоутверждения. В процессе общения юноши (девушки) решают круг проблем, связанных с их становлением и реализацией как субъектов отношений, что и определяет ценностноориентирующий характер содержания общения в этом возрасте.

Но виртуальное общение (в социальных сетях) теряет многие из характеристик реального общения: в частности, нивелируется невербальный компонент общения, а также не развивается устная речь, что естественно отражается и на самом субъекте этого общения, формируя у него иные качества, чем в реальном общении. Еще одной особенностью коммуникации посредством компьютера является то, что в ней не возникает привычный для реального общения образ партнера, опирающийся прежде всего на зрительный компонент, а другой человек воспринимается как «список» характеристик, представленных в виде текста.

Эти примеры показывают, что в виртуальной коммуникации у личности формируются специфические способы и средства общения и становятся иными механизмы восприятия человека человеком (например, не используется эмпатия, нивелируется эмоциональный компонент, изменяются способы 
категоризации и оценки партнера и т.д.). Учитывая, что такой опыт приобретает только еще формирующийся субъект межличностных отношений и общения, можно предположить, что произойдет формирование иного субъекта отношений, чем это происходит в реальном общении.

Нами было проведено пилотажное исследование социальнопсихологических особенностей юношей и девушек, увлеченных общением в социальных сетях. Были использованы методики: методика «Диагностика мотивационных ориентаций в межличностных коммуникациях», предложенная И.Д. Ладановым и В.А. Уразаевой и методика диагностики социальнопсихологической адаптации К. Роджерса и Р. Даймонда. В исследовании участвовали 106 юношей и девушек, увлеченных общением в социальных сетях. Они отбирались на основе беседы.

Было выявлено, что отношения с другими людьми у юношей (девушек), увлеченных общением в социальных сетях, характеризуются наличием противоречивых тенденций в поведении: с одной стороны, безоговорочное принятие партнера, готовность обсуждать, что угодно (этим и отличается коммуникация в виртуальном мире от реального общения), с другой стороны стремление к доминированию, нежелание адекватно воспринять, понять в содержательном плане позицию другого человека (в виртуальном общении, прервав диалог, можно без особых усилий отказаться от обсуждения непонятного и неинтересного вопроса). Об этом свидетельствуют высокие значения показателей по шкалам «принятие других», «доминировнаие» (методика Р. Даймонда и К. Роджерса), «ориентация на принятие партнера» (методика И.Д. Ладанова и В.А. Уразаевой) и низкие по шкале «ориентация на адекватность восприятия и понимание партнера», «гармоничность коммуникативных ориентаций», «ориентация на достижение компромисса» (методика И.Д. Ладанова и В.А. Уразаевой).

Можно предположить, что общение в социальных сетях формирует следующую диспозицию личности - «я доброжелательно отношусь к тебе, готов к контакту, но мне безразлично, что ты думаешь и каков ты». Объяснить это можно тем, что при взаимодействии в социальных сетях, если позиция партнера чем-то не устраивает, собеседник может в любой момент прервать контакт без последствий для дальнейшего общения. Поэтому не обязательно понимать позицию другого и разбираться в его понимании ситуации. Если его сообщение произвело на тебя положительное впечатление, ты можешь оставить «лайк», написать комментарий, если же нет, то просто игнорируешь сообщение. В реальном общении, если партнер выдал некое сообщение, ты обязан на него отреагировать.

Таким образом, юноши и девушки, увлеченные общением в социальных сетях, обладают противоречивыми особенностями восприятия другого человека - у них высокий уровень принятия других, доброжелательности и низкий уровень ориентации на адекватное восприятие и понимание партнера по общению, выраженное стремление к доминированию. Выделенные социальнопсихологические особенности проявляются на разных уровнях социального общения: от интимно-личностного до делового. 
Рассмотренные результаты исследования еще раз показали, что компьютеризированное общение приводит к формированию, особенно у взрослеющего человека, качественно иных личностных характеристик, способов взаимодействия с другими людьми, представлений о ценности себя и другой личности (например, тенденция к доминированию и отсутствие интереса к опыту другого человека). Все это говорит о необходимости изучения вопросов становления личности в условиях усиливающегося воздействия компьютерных форм взаимодействия в структуре межличностных отношений юношей и девушек

На сегодняшний день можно с уверенностью констатировать, что условия развития и социализации личности молодого человека (подростка, юноши) очень сильно изменились: его взросление и становление как личности происходит в условиях активного включения в виртуальное общение, которое становится основным способом выстраивания межличностных отношений молодого человека, познания самого себя, личностного самоопределения и социального самоутверждения. Это требует научного изучения и переосмысления механизмов и процессов становления личности в юношеском возрасте

\section{ВЛИЯНИЕ ИНДИВИДУАЛЬНО-ПСИХОЛОГИЧЕСКИХ ОСОБЕННОСТЕЙ ЛИЧНОСТИ НА ЕЁ КОНФОРМНОЕ ПОВЕДЕНИЕ В ПОДРОСТКОВОМ ВОЗРАСТЕ}

Макарова И.Н.

В отдельных аспектах отечественной психологии традиционная основа рассмотрения некоторых психологических феноменов уже не всегда себя оправдывает, необходим новый, возможно интегративный подход к изучению этих феноменов. В поиске этих новых подходов и состоит одна из важнейших задач современных психологов. В данном исследовании нами была предпринята попытка найти такой новый подход к рассмотрению одного из центральных феноменов социального влияния - феномена конформности.

В самом начале работы над изучением данного социальнопсихологического феномена стояла задача глубокого анализа всех накопленных знаний о самом феномене конформности, о его детерминантах, о методах исследования и вообще обо всех его аспектах и проявлениях. Мы столкнулись с тем, что при всём многообразии накопленного учёными-психологами материала, касающегося проблематики социального влияния, у нас не сформировалось единого образа, дающего представление о проявлениях и взаимозависимостях различных аспектов феномена конформности в поведении человека. Существуют модели, представляющие психологический механизм отдельных аспектов конформности; глубоко и всесторонне изучены конформные тенденции в поведении отдельных профессиональных и возрастных групп; выявлено множество личностных и ситуационных факторов конформности, однако целостной картины феноменологии явления нет. Поэтому первой из задач нашей работы стало создание и исследование по 